\title{
Correlations Among Different P-Test Methods Studied in a Network of Hungarian P Fertilization Long-term Field Trials
}

\author{
${ }^{1}$ M. MAGYAR, ${ }^{1}$ P. CSATHÓ, ${ }^{2} \mathrm{~K}$. DEBRECZENI and ${ }^{2} \mathrm{~K}$. SÁRDI \\ ${ }^{1}$ Research Institute for Soil Science and Agricultural Chemistry (RISSAC) of the \\ Hungarian Academy of Sciences, Budapest and ${ }^{2}$ Veszprém University, \\ Georgikon Faculty of Agriculture, Keszthely (Hungary)
}

\begin{abstract}
Introduction
Phosphorus is an essential nutrient for plant growth and the role of $\mathrm{P}$ in the agroecosystem is an important field of agrochemical studies in relation to modern crop production. Long-term field experiments provide unique opportunities for investigating the fate of fertilizer phosphorus $(\mathrm{P})$ in soil. This is of primary importance both from agronomic (recommended fertilizer $\mathrm{P}$ doses for optimum crop yields) and environmental point of view (i.e. accumulation of $\mathrm{P}$ in soil may represent a considerable potential for $\mathrm{P}$ load of surface and subsurface waters via erosion and $\mathrm{P}$ leaching).

The plant available amount of $\mathrm{P}$ in soils can be estimated by different extraction methods. The success of estimating available $\mathrm{P}$ by an extractant depends on the suitability of the chemical used relative to soil properties (SHARPLEY, 2000). In soils with higher buffering capacity, the dissolved P amount can be less, due to exhaustion of the extraction by the higher exchange capacity of soil, or resorption of extracted P. By increasing the solution-to-soil ratio more $\mathrm{P}$ can be extracted from the soils (KAMPRATH \& WATSON, 1980). Acid solvents, however, can behave differently in acidic and calcareous soils. By dissolving Ca-phosphates non-available for plants, these methods often overestimate soil $\mathrm{P}$ supply in calcareous soils (EGNER et al., 1960; LAKANEN \& ERVIÖ, 1971).

The ideal soil P test would take into account intensity (concentration of $\mathrm{P}$ in the soil solution) and quantity (the amount of labile $\mathrm{P}$ adsorbed on the solid phase), buffering power (the ability of soil to maintain solution concentration when solution is depleted by plant uptake or leaching), and diffusion characteristic of the soil. Weak extractants such as water and $\mathrm{CaCl}_{2}$ assess the intensity factor, while strong extractants such as acids, complexing ions, and alkaline buffered solutions measure the quantity factor (KAMPRATH \& WATSON, 1980).
\end{abstract}

Correspondence to: Marianna MAGYAR, Research Institute for Soil Science and Agricultural Chemistry (RISSAC) of the Hungarian Academy of Sciences, H-1022 Budapest, Herman Ottó út 15. Hungary. E-mail: magyar@rissac.hu 
Today's challenge in elaborating a soil test method is to select an extractant that accomodates several factors: 1. Multielement; 2 . suitable for a range of soil characteristics; 3 . having an established relative relationship between elemental level versus crop response (BENTON JONES, 1997).

Nowadays some new methods, among others the anion exchange resin membrane (AERM) and Fe-oxide impregnated paper strip (Pi) tests have attracted interest to assess the "available" phosphorus in soils (VAN RAIJ, 1997). These alternative methods determine the quantity of soil $\mathrm{P}$ available to plants with weak chemical extraction, and their advantage is their adaptability to all types of soils irrespective of fertilization history. The amounts of soil $\mathrm{P}$ desorbed by the AERM- and Pi methods have been found to be closely correlated to each other and with plant P uptake (DALAL, 1985; INDIATI et al., 1998; LIN et al., 1991). These methods simulate conditions similar to those occurring in the soil solution from which plants adsorb P (MENON et al., 1988). The Fe-oxide impregnated paper strip removes primarily physically bound $\mathrm{P}$ from both calcareous and non-calcareous soils. The Pi method describes soil $\mathrm{P}$ availability across a wide range of soil properties more accurately than other methods (SHARPLEY, 1991).

In Hungary the AL method (using $0.1 \mathrm{M}$ ammonium lactate and $0.4 \mathrm{M}$ acetic acid as extractant) has been the official soil P-test method since the 1960's (EGNER et al., 1960). The measured AL-P values, however, are strongly influenced by soil properties (such as: soil reaction status and carbonate content). Using Neubauer test trials on large numbers of Hungarian soils with a wide range of soil properties SARKADI et al. (1984) corrected the AL-P values to standard soil characteristics (soil texture, $\mathrm{pH}$ and $\mathrm{CaCO}_{3}$ content). On a wide range of soils, the corrected AL-P values show much better connection with the plant $P$ uptake than the AL-P values.

Seeking relationships among various extractants used in soil analysis is the objective of several studies looking for conversion equations among the different methods and studying the effect of soil properties on relative extractability of nutrients in soil (SHERRELL, 1970.; KLEINMAN et al., 2001). The determination of such equations is especially important when studying a new soil test method, as it allows the use of relations between soil nutrient contents and crop response evaluated by the method which is used.

\section{Material and Methods}

The National Long-term Field Trials (NLFT) were set up in 1967 at 26 different sites, representing the main agro-ecological regions of the country. Due to the lack of adequate financial support, the experiments are carried on nowadays only at 9 sites. 
Fertilizer treatments were uniformized for all sites, including increasing nitrogen, phosphorus and potassium rates and combinations of these mineral fertilizers. From the original 20 treatments with 4 replications, 4 treatments were selected for this study from each site: $\mathrm{N}_{2} \mathrm{P}_{0} \mathrm{~K}_{1} ; \mathrm{N}_{2} \mathrm{P}_{1} \mathrm{~K}_{1} ; \mathrm{N}_{2} \mathrm{P}_{2} \mathrm{~K}_{1}$ and $\mathrm{N}_{4} \mathrm{P}_{3} \mathrm{~K}_{2}$. $\mathrm{N}_{2}$ refers to annual $150, \mathrm{~N}_{4}$ to $250 \mathrm{~kg} \mathrm{~N} \mathrm{ha}^{-1}$, while $\mathrm{K}_{1}$ to $200, \mathrm{~K}_{2}$ to 250 $\mathrm{kg} \mathrm{K}_{2} \mathrm{O} \mathrm{ha}^{-1}$. The amounts of $\mathrm{P}$ given were $0,60,120$ and $180 \mathrm{~kg} \mathrm{P}_{2} \mathrm{O}_{5} \mathrm{ha}^{-1}$ annually, according to the different $\mathrm{P}$ levels $\left(\mathrm{P}_{0}-\mathrm{P}_{3}\right)$. Both the $\mathrm{N}_{2}$ and $\mathrm{N}_{4}$, as well as the $\mathrm{K}_{1}$ and $\mathrm{K}_{2}$ levels refer to good NK supply.

The aim of this study was to compare some soil P-tests, including two innovative methods, on 9 soils of the NLFT. The studied soils - sampled in 1994, in the $27^{\text {th }}$ year of the experiment - represented six FAO soil units (Calcaric Phaeosem, Luvic Phaeosem, Haplic Phaeosem, Ochric Luvisol, Eutric Cambisol, Calcaric Fluvisol) (SÁRDI \& NÉMETH, 1993), or seven USDA units (Calcic Hapludoll, Aquic Hapludoll, Typic Endoaquoll, Typic Argiudoll, Typic Hapludalf, Typic Udifluvent, Orthic Eutrochrept) (SÁRDI \& CSATHÓ, 2002), belonging to four different soil texture classes (clay, clay loam, loam, sandy loam). Other properties were: $\mathrm{pH}(\mathrm{KCl}): 3.9-7.4 ; \mathrm{y}_{1}$ (meq/100 g): 0-24; $\mathrm{CaCO}_{3} \%$ : 0 21; clay \%: 12-41. The effect of uniform fertilization on soil P-test values can be examined under a wide range of soil properties (DEBRECZENI \& DEBRECZENI, 1994).

The AL-, Olsen-, $\mathrm{H}_{2} \mathrm{O}-$, Pi- and AERM methods were used for estimating avaiable soil phosphorus (Table 1). There were calculated corrected AL-P values on the principle of converting AL-P values obtained on various soils to standard soil properties (loam soil texture, $6.8 \mathrm{pH}(\mathrm{KCl}), 0.1 \% \mathrm{CaCO}_{3}$ ), determined by using Neubauer test trials on large numbers of Hungarian soils with a wide range of soil properties (SARKADI et al., 1984). Linear equations were calculated for determining the correlation between soil P-test methods.

Table 1

Extraction methods for soil available phosphorus

\begin{tabular}{|c|c|c|c|}
\hline Method & Solution & $\begin{array}{c}\text { Soil to } \\
\text { solution } \\
\text { ratio } \\
(\mathrm{w} / \mathrm{v})\end{array}$ & $\begin{array}{c}\text { Extrac- } \\
\text { tion } \\
\text { time }\end{array}$ \\
\hline AL-P ${ }^{1}$ & $0.1 M \mathrm{NH}_{4}$-lactate $+0.4 \mathrm{MCH}_{3} \mathrm{COOH}$ & $1: 20$ & $120 \mathrm{~min}$. \\
\hline $\mathrm{Pi}-\mathrm{P}^{2}$ & $0.01 M \mathrm{CaCl}_{2}+\mathrm{Fe}$-oxide coated strip & $1: 40$ & 16 hours \\
\hline AERM-P ${ }^{3}$ & $\mathrm{H}_{2} \mathrm{O}+$ anion exchange resin membrane* & $1: 30$ & 16 hours \\
\hline $\mathrm{H}_{2} \mathrm{O}-\mathrm{P}^{4}$ & Bidistilled water & $1: 50$ & 2 hours \\
\hline Olsen- $\mathrm{P}^{5}$ & $0.5 \mathrm{M} \mathrm{NaHCO}_{3}$ & $1: 20$ & $30 \mathrm{~min}$. \\
\hline
\end{tabular}

${ }^{1}$ Egner et al., 1960; ${ }^{2}$ MenON et al., 1988; ${ }^{3}$ SAGgar et al., 1990; ${ }^{4}$ SCHACHTSCHABEL, 1973, modified by SARKADI, $1982 ;{ }^{5}$ OLSEN et al., $1954 ; * \mathrm{HCO}_{3}{ }^{-}$form 
Table 2

The effect of 27 years $\mathrm{P}$ fertilization on the P-test values

(Network of National Long-term Field Trials, 1994)

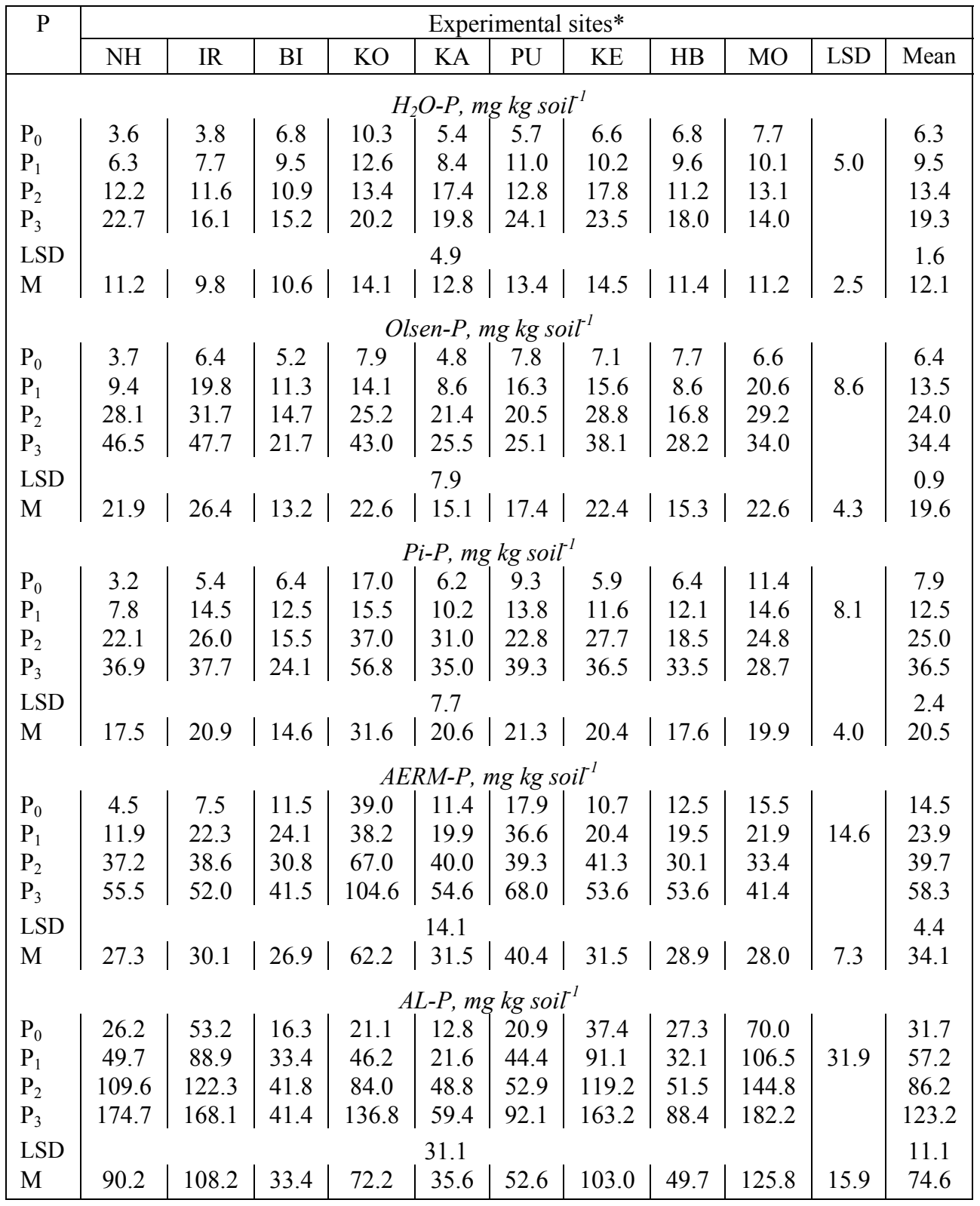

* Experimental sites: NH: Nagyhörcsök; IR: Iregszemcse; BI: Bicsérd; KO: Kompolt; KA: Karcag; PU: Putnok; KE: Keszthely; HB: Hajdúböszörmény; MO: Mosonmagyaróvár $\mathrm{LSD}=\mathrm{LSD}_{5^{\circ}} ; \mathrm{M}=$ Mean 


\section{Results}

The effect of $\mathrm{P}$ application on the soil P-test values was significant on the different $P$ levels and sites (Table 2). There were great differences, however, in the amounts of $\mathrm{P}$ dissolved by the different methods. The average effect of the sites varied between $1.5-3.7$-fold $\left(\mathrm{H}_{2} \mathrm{O}\right.$ method-AL method). The acidic $\mathrm{AL}$ method was most dependent on the soil reaction and lime status. The highest AL-P values were extracted on the calcareous sandy loam-loam soils with low clay content, meanwhile the lowest AL-P values were obtained on acidic clay loam soils.

P fertilization resulted in a 3-5-fold increase in soluble P contents regarding the different P-test methods, and the absolute values of dissolved $\mathrm{P}$ varied greatly $\left(\mathrm{H}_{2} \mathrm{O}-\mathrm{P}\right.$ : 3.6-23.5; Olsen-P: 3.7-48; Pi-P 3.2-56.8, AERM-P: 4.5-104.6; and AL-P: $12.8-182.2 \mathrm{mg} \mathrm{P} \mathrm{kg}^{-1}$ ).

The amounts of extracted $\mathrm{P}$ increased in the order of: $\mathrm{H}_{2} \mathrm{O}-\mathrm{P}<$ Olsen-P $<$ Pi-P $<$ AERM-P $<$ AL-P $<$ corrected AL-P. Taking the AL-method - which is the official soil P-test method in Hungary - as the reference method (100\%), this sequence can be expressed by calculating the $\%$ ratios between mean values of the P extracted by various methods: $16<26<28<46<100<115$.

When studying the relationship between the $\mathrm{P}$ values extracted by the different methods, different soil groups (acidic, calcareous and all soils) were taken into consideration as a basis.

Acidic soils (Table 3): The strongest correlation was found between the ALand the Corr. AL-P methods $\left(\mathrm{r}=0.98^{* *}\right)$. As it was mentioned above, among soil properties, soil $\mathrm{CaCO}_{3}$ content is the one that mainly determines the AL-P values. Within the acidic soil group, $\mathrm{pH}$ has a much less expressed effect on these values. This may be the reason why the AL-P and corrected AL-P values showed the strongest correlation within this group.

Table 3

Correlation coefficient (r) matrix for different methods of extracting soil phosphorus - acidic soils $(\mathrm{n}=16)$

\begin{tabular}{|l|l|l|l|l|l|l|}
\hline & \multicolumn{1}{|c|}{ AL-P } & Corr.AL-P & \multicolumn{1}{c|}{ Pi-P } & AERM-P & \multicolumn{1}{c|}{$\mathrm{H}_{2} \mathrm{O}-\mathrm{P}$} & Olsen-P \\
\hline AL-P & 1 & & & & & \\
Corr.AL-P & $0,9804^{* *}$ & 1 & & & & \\
Pi-P & $0,9449^{*}$ & $0,9105^{*}$ & 1 & & & \\
AERM-P & $0,9680^{* *}$ & $0,9489^{*}$ & $0,9663^{* *}$ & 1 & & \\
$\mathrm{H}_{2} \mathrm{O}-\mathrm{P}$ & 0,8032 & 0,7637 & $0,8802^{*}$ & 0,8233 & 1 & \\
Olsen-P & $0,9515^{*}$ & 0,9014 & $0,9618^{* *}$ & $0,9463^{*}$ & 0,8450 & 1 \\
\hline
\end{tabular}

*significant at $0.05 ; * *$ significant at $0.01 ; * * *$ significant at 0.001 probability level 
Within the acidic soils group, other close correlations were found between the AL- and AERM-P $\left(\mathrm{r}=0.97^{* *}\right)$, and between the Pi- and AERM-P methods $(\mathrm{r}=0.97 * *)$.

Calcareous soils (Table 4): The best correlation was found between the two innovative methods: the Pi- and AERM-P $\left(\mathrm{r}=0.99^{* * *}\right)$. The AL-P method showed the best relationship with the Olsen-P method $\left(\mathrm{r}=0.93^{* *}\right)$.

Table 4

Correlation coefficient (r) matrix for different methods of extracting soil phosphorus - calcareous soils $(n=20)$

\begin{tabular}{|l|l|l|l|l|l|l|}
\hline & \multicolumn{1}{|c|}{ AL-P } & Corr.AL-P & \multicolumn{1}{c|}{ Pi-P } & AERM-P & \multicolumn{1}{c|}{$\mathrm{H}_{2} \mathrm{O}-\mathrm{P}$} & Olsen-P \\
\hline AL-P & 1 & & & & & \\
Corr.AL-P & 0,6473 & 1 & & & & \\
Pi-P & $0,8684^{*}$ & 0,7894 & 1 & & & \\
AERM-P & $0,8298^{*}$ & 0,8092 & $0,9918^{* * *}$ & 1 & & \\
$\mathrm{H}_{2} \mathrm{O}-\mathrm{P}$ & 0,7881 & $0,8910^{*}$ & $0,9359^{* *}$ & $0,9459^{* *}$ & 1 & \\
Olsen-P & $0,9307^{* *}$ & 0,6905 & $0,9579^{* *}$ & $0,9411^{* *}$ & $0,8711^{*}$ & 1 \\
\hline
\end{tabular}

*significant at $0.05 ; *$ significant at $0.01 ; * *$ significant at 0.001 probability level

All soils (Table 5): The best correlation was found between the Pi- and AERM-P $\left(\mathrm{r}=0.96^{* * *}\right)$ and the Pi- and $\mathrm{H}_{2} \mathrm{O}-\mathrm{P}$ methods $(\mathrm{r}=0.90)$. Other close correlations were obtained between the Pi- and Olsen-P $\left(\mathrm{r}=0.88^{* * *}\right)$, and between the AL- and Olsen-P methods $\left(\mathrm{r}=0.89^{* * *}\right)$, presumably indicating that these methods extracted $\mathrm{P}$ from the similar soil-P fraction. The lactic and alkaline extractants dissolve both adsorbed phosphates and Fe-, Al-phosphates and easily dissolvable Ca-phosphates. Otherwise the lactic acid extractants dissolve a considerable amount of the less soluble Ca-phosphates, however this fraction of $\mathrm{P}$ is unavailable for plants (FÜLEKY, 1976a,b).

Table 5

Correlation coefficient ( $\mathrm{r}$ ) matrix for different methods of extracting soil phosphorus - all soils $(\mathrm{n}=36)$

\begin{tabular}{|l|l|l|l|l|l|l|}
\hline & \multicolumn{1}{|c|}{ AL-P } & Corr.AL-P & \multicolumn{1}{c|}{ Pi-P } & AERM-P & \multicolumn{1}{c|}{$\mathrm{H}_{2} \mathrm{O}-\mathrm{P}$} & Olsen-P \\
\hline AL-P & 1 & & & & & \\
Corr.AL-P & 0,5327 & 1 & & & & \\
$\mathrm{Pi}-\mathrm{P}$ & $0,6928^{*}$ & $0,8557 * *$ & 1 & & & \\
AERM-P & 0,5651 & $0,8994 * * *$ & $0,9618^{* * *}$ & 1 & & \\
$\mathrm{H}_{2} \mathrm{O}-\mathrm{P}$ & $0,6343 *$ & $0,7894 * *$ & $0,9027 * * *$ & $0,8542 * *$ & 1 & \\
Olsen-P & $0,8977^{* * *}$ & $0,6710^{*}$ & $0,8847 * * *$ & $0,7912 * *$ & $0,8159 * *$ & 1 \\
\hline
\end{tabular}

*significant at $0.05 ; * *$ significant at $0.01 ; * *$ significant at 0.001 probability level 

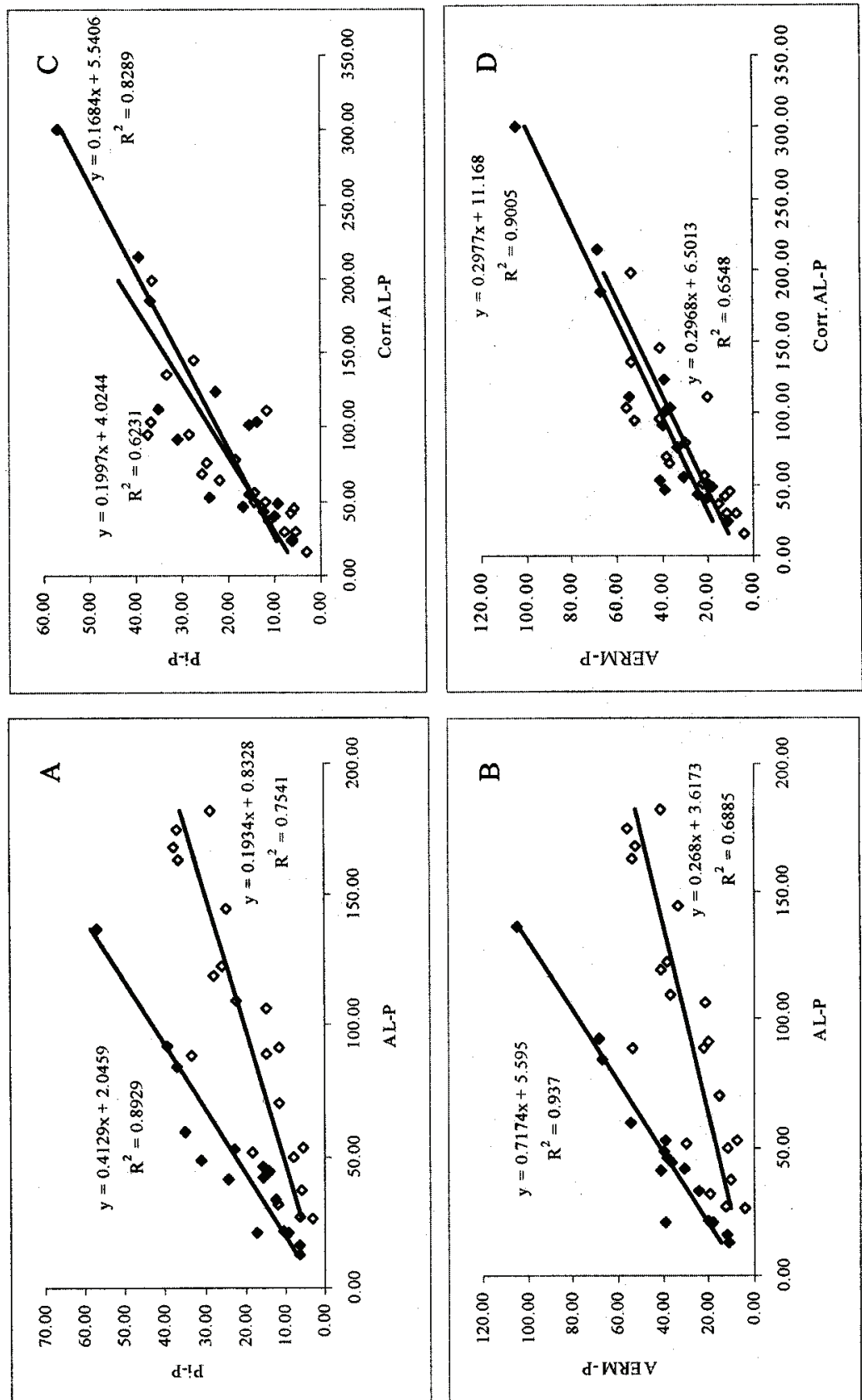

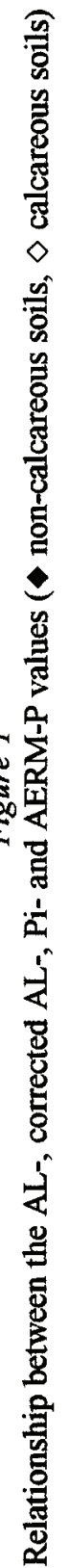


Weak correlations were detected between the AL- and the innovative P-test methods (AL-Pi: $r=0.70^{*}$; AL-AERM: $r=0.56$ ). The reason of this is that the AL-P values depend considerably on the $\mathrm{CaCO}_{3}$ status of soils, while the two innovative methods are much less dependent on soil properties. There are two ways to increase the strength of correlation between the four methods:

- to determine new relations dividing soils into calcareous and non-calcareous groups (Figure 1. A, B), or

- to convert the AL-P values to standard soil properties, and afterwards determine relations between the corrected AL-P and Pi-P, or corrected AL-P and AERM-P values (corrected AL-Pi: $\mathrm{r}=0.86^{* *}$; corrected AL-AERM: $\mathrm{r}=$ $0.90 * * *$ ) (Figure 1. C, D).

The corrected AL-method is expected to improve the correlation between crop P uptake and soil P-test values, because this method could abolish differences developed in calcareous and non-calcareous soil groups by using the AL-method.

\section{Summary}

Five soil P-test methods were compared on the soils of the network of unified Hungarian P fertilization long-term field trials. The effect of P application on the soil P-test values was significant on the different $\mathrm{P}$ levels and sites. The average effect of the sites varied between 1.5 -fold $\left(\mathrm{H}_{2} \mathrm{O}\right.$ method) and 3.7fold (AL-method).

The amounts of extracted $\mathrm{P}$ increased in the order of $\mathrm{H}_{2} \mathrm{O}-\mathrm{P}<$ Olsen-P $<$ Pi$\mathrm{P}<$ AERM-P $<$ AL-P $<$ Corrected AL-P. For studying the relationships between the $\mathrm{P}$ values extracted by the different methods, acidic, calcareous and all soils groups were taken into account as a basis. A good correlation was found between the Pi- and AERM-methods in each soil group. Within the acidic soil group, $\mathrm{pH}$ has a much less expressed effect on AL-P values, presumably this was the reason why the strongest correlation in this soil group was found between the AL- and the Corr. AL-P methods

The next step in our research will be to calibrate these soil-P tests with plant $\mathrm{P}$ uptake and yield responses.

Key words: Hungarian field trials, AL-P, AERM-P, Pi-P, corrected AL

This research was supported by the National Scientific Research Fund (OTKA) under Project No. T 029355. 


\section{References}

BENTON JoNeS, J. JR., 1997. Soil test methods; past present and future use of soil extractants. Comm. Soil Sci. Plant Anal. 29. 1543-1552.

DALAL, R. C., 1985. Comparative prediction of yield response and phosphorus uptake from soil using anion and cation-anion-exchange resins. Soil Sci. 139. 227-231.

DebrecZeni, B. \& DebreCZENI, K. (Eds.) 1994. Fertilization Researches, 1960-1990. (In Hungarian) Akadémiai Kiadó. Budapest.

EGNER, H. et al., 1960. Untersuchungen über die chemische Bodenanalyse als Grundlage für die Beurteilung de Nährstoffzustandes der Böden. II. K. LantbrHögsk. Ann. 26.199.

FÜLEKY, GY., 1976a. Investigation on some extractants used for the evaluation of available phosphorus. I. Extraction of the soils with AL-, DL-, CAL-, Bray I-, $\mathrm{NaHCO}_{3^{-}}, \mathrm{NaHCO}_{3}+\mathrm{NH}_{4} \mathrm{~F}-$ and $\mathrm{CaCl}_{2^{-}}$solutions before fractionation. (In Hungarian) Agrokémia és Talajtan. 25. 271-283.

FÜLEKY, GY., 1976b. Investigation on some extractants used for the evaluation of available phosphorus. II. Correlation between AL-, DL-, CAL-, Bray I-, $\mathrm{NaHCO}_{3^{-}}$, $\mathrm{NaHCO}_{3}+\mathrm{NH}_{4} \mathrm{~F}$ - and $\mathrm{CaCl}_{2}$-soluble phosphorus and the inorganic phosphate fractions. (In Hungarian) Agrokémia és Talajtan. 25. 284-295.

INDIATI, R. et al., 1998. Comparison of chemical extractants and phosphorus-sink methodologies in assessing available phosphate in Sardinian pasture soils. Agricoltura Mediterranea. 128. 255-265.

KAMPRATH, E. J. \& WATSON, M. E., 1980. Conventional soil and tissue tests for assessing the phosphorus status of soils. In: The Role of Phosphorus in Agriculture. (Eds.: Khasawneh, F. E., Samle, E. C. \& Kamprath, E. J.) 433-369. ASA, CSSA, SSSA, Madison, WI.

KLEINMAN, P. J. A. et al., 2001. Interlaboratory comparison of soil phosphorus extracted by various soil test methods. Commun. Soil Sci. Plant Anal. 32. 23252345.

LAKANEN, E. \& ERVIÖ, R., 1971. A comparison of eight extractants for the determination of plant available micronutrients in soils. Acta Agric. Fenn. 123. 223-232.

LIN, T. H. et al., 1991. The use of iron oxide-impregnated paper for the extraction of available phosphorus from Taiwan soils. Plant \& Soil. 133. 219-226.

MENON, R. G. et al., 1988. Determination of plant available phosphorus by the iron hydroxide-impregnated filter paper soil test. Soil Sci. Soc. Am. J. 52. 110-115.

OlsEN, S. R. et al., 1954. Estimation of Available Phosphorus in Soils by Extraction with Sodium Bicarbonate. Circular No. 939. USDA. Washington, D. C.

SCHACHSCHABEL, P., 1973. Beziehungen zwischen dem Phosphorgehalt in Böden und jungen haferpflanzen. Zeirschrift Pflanzenern. Bodenkunde. 135. 31-43.

SAGGAR, S. M. et al., 1990. A simplified resin membrane technique for extracting phosphorus from soils. Fert. Res. 24. 173-180.

SÁRDI, K. \& CSATHÓ, P., 2002. Studies on the phosphorus dynamics in pot experiments with different soil types. Commun. Soil Sci. Plant Anal. 33. (In press)

SÁRDI, K. \& NÉMETH, T., 1993. Studies on the available K content of different soils at constant moisture. Agrokémia és Talajtan. 42. 183-194. 
SARKADI, J., 1982. Opredelenie „vodorastvorimogo“ fosfora. In: Agrochemische Methoden für die Untersuchung des phosphathaushaltes des Böden: Methodensammlung. 1-13. Ak. der Landw. DDR. IPE. Jena.

SARKADI, J. et al., 1984. Possibility of the application of AL-P-values corrected by some soil characteristics for the estimation of the P-availability in soils. In: Proc. $9^{\text {th }}$ World Fertilizer Congress. Vol. 2. 319-323. CIEC-Goeltze Druck. Göttingen.

Sharpley, A. N., 1991. Soil phosphorus extracted by iron-aluminium-oxide-impregnated filter paper. Soil Sci. Soc. Am. J. 55. 1038-1041.

Sharpley, A. N., 2000. Phosphorus avilability. In: Handbook of Soil Science (Ed: SUMNER, M. E.) D18-D38. CRC Press. Boca Raton

SHERRELL, C. G., 1970. Comparison of chemical extraction methods for the determination of "available" phosphate in soils. I. Correlation between methods and yield and phosphorus uptake by white clover grown on 16 North Island soils in the glasshouse. New Zealand Journal of Agricultural Research. 13. (3) 481-493.

VAN RAIJ, B., 1997. Bioavailable tests: alternatives to standard soil extractions. Comm. Soil Sci. Plant Anal. 29. 1553-1570 